\title{
ON THE SYNTAX OF DITRANSITIVE SENTENCES IN SLOVENIAN
}

\author{
TATJANA MARVIN-ADRIAN STEGOVEC \\ Univerza v Ljubljani \\ Aškerčeva 2 \\ 1000 Ljubljana \\ Slovenia \\ tatjana.marvin@ff.uni-lj.si; adrian.stegovec@gmail.com
}

\begin{abstract}
In this paper we discuss Slovenian ditransitive sentences with respect to the two possible word orders of the objects found with neutral intonation, DAT》ACC and ACC $\gg$ DAT. We follow the idea in the Gračanin-Yuksek (2006) paper on Croatian that these two word orders instantiate different structures. In Slovenian, the DAT $\gg A C C$ order has an applicative structure (either high or low), while the ACC $\gg D A T$ is a prepositional dative construction. The applicative analysis provides a novel argument for this type of analysis. Other supporting arguments examined are scope properties, binding of possessives, the possibility of the causative reading, non-contrastive focus and heavy NP shift, and properties of idioms.
\end{abstract}

Keywords: ditransitives, high applicatives, low applicatives, double object construction, prepositional dative construction, Slovenian

\section{Introduction}

In Slovenian, ditransitive sentences show ambiguity with respect to the low and high applicative reading as defined in the Pylkkänen (2002; 2008) framework. Both readings are available with send-and throw-type verbs; however, give-type verbs exclude the high and appear with the low applicative reading only, suggesting that the availability of applicative meanings is linked to the inherent meaning of the verb in the VP. In this paper we discuss the existence of an additional constraint on high applicative readings. 
This other restriction appears to be tied to different surface word orders in ditransitive sentences. Gračanin-Yuksek (2006) shows for Croatian, which has what appears to be an identical set of possible word orders, that these are linked to two different ditransitive constructions that behave like the English prepositional dative (PDC hereafter) and double object (DOC hereafter) constructions. In the same vein the different Slovenian word orders are analyzed in Stegovec (to appear) (repeated in this paper) with standard tests for c-command asymmetries (Barss-Lasnik 1986; Larson 1988; Pesetsky 1995), frozen scope relations (Aoun-Li 1989; Bruening 2001), and the availability of causative readings (Oehrle 1976; Gračanin-Yuksek 2006). The tests indicate that the dative $\gg$ accusative (DAT $\gg$ ACC) word order is an applicative construction, while the accusative $\gg$ dative $(\mathrm{ACC} \gg \mathrm{DAT})$ has a structure similar to an English PDC.

Our proposal is that the DAT $\gg \mathrm{ACC}$ word order is - except with give-type verbs - ambiguous between the low and the high applicative, while in ACC $\gg$ DAT, a Slovenian analogue of the PDC, which is normally tied to a meaning closer to the low applicative, the high applicative reading is unavailable.

Table 1

Proposal

$\frac{\text { DAT } \gg \text { Verb } \gg \text { ACC }}{\text { low applicative }}$
high applicative

The paper is organized as follows. In section 2 the basic Slovenian ditransitive word orders are put through standard tests for different ditransitive constructions and the possibility of derivation through A-scrambling is examined. Section $\mathbf{3}$ contains a description of the main characteristics of Slovenian applicative constructions (3.1) and then links them to the three ditransitive word orders $(\mathbf{3 . 2})$. Section 4 deals with some remaining issues: 4.1 comparing our analysis of Slovenian ditransitives with a similar proposal for Czech in Dvořák (2010) and $\mathbf{4 . 2}$ examining the absence of pure locatives expressed by dative DPs in Slovenian PDC-like constructions. 


\section{The three Slovenian ditransitive word orders}

In this section we show that Slovenian has at least two ditransitive constructions, which are manifested syntactically through the surface order of the direct and indirect object. The word order in Slovenian ditransitive sentences appears to be relatively free; however, the three word orders in (1) are the only neutral ones, all other variations are achieved through topicalization and contrastive or non-contrastive focus. ${ }^{1}$

(1) (a) Ema Kaji daje knjigo.

Ema.nom Kaja.dat give.pres book.acc

'Ema is giving Kaja the book.'

(b) Ema daje Kaji knjigo.

Ema.nom give.pres Kaja.dat book.acc

'Ema is giving Kaja the book.'

(c) Ema daje knjigo Kaji.

Ema.nom give.pres book.acc Kaja.dat

'Ema is giving the book to Kaja.'

Following the non-derivational/polysemy approach to dative alternation (Oehrle 1976; Jackendoff 1990; Pesetsky 1995 and similar work), we assume that different dative constructions have distinct underlying structures and are not transformationally related. If this is correct, the different word orders should exhibit c-command asymmetries as well as differences in meaning.

\subsection{Binding of possessives}

In Barss-Lasnik (1986); Larson (1988) ${ }^{2}$ and Pesetsky (1995) asymmetries in the binding of possessives are used to identify two separate

${ }^{1}$ In Gračanin-Yuksek (2006) the position of the verb with respect to the dative argument is important, (1a) and (1b) yielding different structures. In Slovenian, the position of the verb is irrelevant, the only important factor is the order of the dative and accusative arguments, regardless of the actual position that the two arguments have in the sentence with respect to other sentence elements. For example, if the subject is not expressed by a DP but only through the verbal ending as e.g., in (22a), the dative argument can appear at the beginning of the sentence with neutral intonation.

${ }^{2}$ In his paper Larson subscribes to a derivational approach to dative alternations and explains the c-command asymmetries with different surface structure posi- 
ditransitive constructions with reversed c-command relations. The Slovenian examples in (2) below show, using the same test, that the different word orders cannot be derived by optional $\overline{\mathrm{A}}$-scrambling, since binding relations change with the order of arguments.

(2) (a) $\mathrm{Tat}_{j}$ je [vsakemu oškodovancu $]_{i}$ vrnil $\left[\operatorname{svoj}_{i, j}\right.$ avto $]$.

thief $_{j}$ aux $[\text { each victim.dat }]_{i}$ return.past $\left[\right.$ his $_{i, j}$ car.acc $]$

'The thief returned every victim his car.'/'The thief returned every victim his (the thief's) car.'

(b) Tat $_{j}$ je vrnil [vsakemu oškodovancu $]_{i}\left[\operatorname{svoj}_{i, j}\right.$ avto $]$. thief $_{j}$ aux return.past [each victim.dat $]_{i} \quad\left[\operatorname{his}_{i, j}\right.$ car.acc $]$.

'The thief returned every victim his car.'/'The thief returned every victim his (the thief's) car.'

(c) Tat $_{j}$ je vrnil $\left[\operatorname{svoj}_{* i, j}\right.$ avto $]$ [vsakemu oškodovancu $]_{i}$. thief $_{j}$ aux return.past $\left[\right.$ his $_{* i, j}$ car.acc $][\text { each victim.dat }]_{i}$

"*The thief returned every victim his car.'/The thief returned every victim his (the thief's) car.'

The proposed c-command relations for the examples in (2) are exemplified in (3) below. ${ }^{3}$

(3) (a) \& (b)

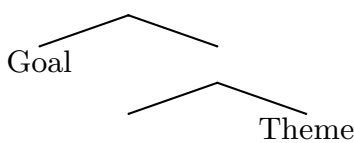

(c)

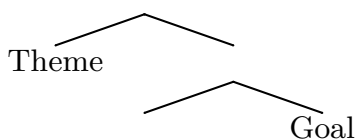

In terms of c-command relations the DAT $\gg \mathrm{ACC}$ word order $(3 \mathrm{a}-\mathrm{b})$ mirrors the English DOC, while the ACC $\gg$ DAT (3c) mirrors the PDC. But this alone does not rule out an A-scrambling analysis, since it predicts the same binding relations as two distinct constructions. ${ }^{4}$

Following McGinnis (1999), A-scrambling is A-movement and can feed binding when the bound pronoun is embedded in an object nominal phrase. It, however, violates binding when the reflexive anaphor is itself the object, as seen in her examples from Georgian in (4) below.

tions of the two objects. This, however, has no bearing on our claim, since at this point we are only showing that the three Slovenian constructions are not instances of optional $\overline{\mathrm{A}}$-scrambling, which would not change binding relations.

${ }^{3}$ We use Goal in this paper as an umbrella term for Goal, Recipient as well as Beneficiary in cases where the more fine grained semantic distinctions between them are irrelevant.

${ }^{4}$ We thank one of the anonymous reviewers for pointing this out to us. 
(4) (a) Nino-s tavisi $_{i}$ deida [t xaTav-s].

(b) $*$ Vano-s $_{i} \quad$ tavisi tav- $\mathrm{i}_{i}[\mathbf{t}$ xaTav-s].

Vano.dat self.nom draw.pres

'Himself $i$ is drawing $\mathbf{V a n o}_{i}$.'

This contrast cannot be shown in Slovenian ditransitive constructions, since Slovenian reflexive pronouns only bind with subjects. Other constructions are also problematic due to the lack of objects with nominative case. And if the moved constituent is the anaphoric one, as in (5) below, violation of binding is expected in any case. However, in Slovenian these sentences are already ungrammatical without the binding violation. ${ }^{5}$

(5) (a)
(a) ${ }^{*}$ Sebe $_{i} \quad$ Tone $_{i}$ riše t.
himself.acc Tone.nom draw.pres
'Tone is drawing himself.'
(b) ${ }^{*}$ Svoj $_{i}$ avto Tone $_{i}$ vozi t.
[his car].acc Tone.nom drive.pres
'Tone is driving his car.'

The sentence in (6b) below, derived from (6a), is a potential case of A-scrambling feeding binding.

(6) (a) ${ }^{*} \mathrm{Njen}_{i}$ brat pomaga $\mathrm{Kaji}_{i}$.

[her brother].nom help.pres Kaja.dat

'Her brother is helping Kaja.'

(b) ${ }^{? ?} \mathbf{K a j i}_{i} \quad$ njen $_{i}$ brat pomaga t.

Kaja.dat[her brother].nom help.pres

'Kaja is helped by her brother.'

However, (6b) is not completely grammatical, because this word order is only possible where pomaga is non-contrastively focused (discussed in section 2.4) or if either pomaga or njen brat carries prosodic prominence.

${ }^{5}$ They are only grammatical as a contextual clarification, where both the question word in the question and the "moved" constituent in the answer are expressed with prosodic prominence, similar to English examples: Who is Tone drawing?!/It is himself f $_{i}$ that Tone $_{i}$ is drawing and What is Tone driving?!/It is his car , that $^{2}$ Tone $_{i}$ is driving. However, in such cases binding is not affected, so they cannot be instances of A-scrambling or any other type of A-movement. 
This indicates that other processes are involved in the derivation, since with scrambling both the base and derived sentence should differ only in word order.

Miyagawa (1997) offers a different test for A-scrambling. He shows that with ditransitive idiomatic expressions the direct object can only undergo A-scrambling clause-internally. If it scrambles out of the embedded clause, the sentence can only be interpreted literally:

(7) (a) Te-o John-ga [hoteru-gyoo-ni [t nobasita]].

(Miyagawa 1997)

hand.ace John.nom hotel-biz.dat extended

'John became involved in the hotel business.'

(lit. 'John extended his hand to the hotel business')

(b) \#Te-o Mary-ga John-ga [[hoteru-gyoo-ni [t nobasita]] to] hookokusita.

hand.ace M.nom J.nom hotel-biz.dat extended that reported

*'Mary reported that John became involved in the hotel business.'

(lit. 'Mary reported that John extended his hand to the hotel business.')

When applied to Slovenian, with an idiomatic expression consisting of a verb and direct object, the sentence is ungrammatical when the object is just scrambled over the subject clause-internally as in (8b). And even if other adjustments are made to the word order, the sentence remains at most borderline grammatical as in $(8 \mathrm{c})$ and $(8 \mathrm{~d}) .{ }^{6}$ It is the same with the embedded clause-(8f) is completely ungrammatical, and there is no literal/idiomatic interpretation distinction.

(8) (a) Janez nam prodaja [mačka v žaklju].

Janez.nom we.dat sell.pres [cat in sack.acc]

'Janez is selling us a pig in a poke.'

(lit. 'Janez is selling us a cat in a sack.')

(b) *[Mačka v ̌̌aklju $]$ Janez nam prodaja t.

[cat in sack.acc] Janez.nom we.dat sell.pres

(c) ??[Mačka v žaklju] nam prodaja Janez.

[cat in sack.acc] we.dat sell.pres Janez.nom

(d) ??[Mačka v žaklju] nam Janez prodaja.

[cat in sack.acc] we.dat Janez.nom sell.pres

${ }^{6}$ The same meaning as mentioned in footnote 5 makes these examples grammatical; however, this applies to the cases without as well as to the cases with the embedded relative clause. 
(e) Maja ve, [da nam Janez prodaja [mačka v žaklju]]. Maja.nom know.pres [that we.dat Janez.nom sell.pres [cat in sack.acc]] 'Maja knows that Janez is selling us a pig in a poke.'

(f) $*[$ Mačka v žaklju $]$, Maja ve, [da nam Janez prodaja t $]$. [cat in sack.acc] Maja.nom know.pres [that we.dat Janez.nom sell.pres]

While the failure of the tests above cannot in itself prove that the different word orders in Slovenian ditransitive sentences are not derived by A-scrambling, it does show: (a) that standard tests for it are mostly inapplicable to Slovenian, and (b) if Slovenian does allow A-scrambling, it is only present in ditransitive constructions, since other potential instances display further changes in meaning and intonation usually not associated with A-scrambling.

We therefore believe that assuming distinct base constructions instead of derivation by A-scrambling is the simpler solution that introduces less language specific theoretical machinery and is thus preferable. ${ }^{7}$

\subsection{Frozen scope}

In English, ditransitive constructions can be distinguished with regard to the difference in the scope of quantifiers in the direct and indirect object. As discussed in Aoun-Li (1989) and Bruening (2001), scope is frozen in DOCs, where only the surface reading of quantifiers is possible, and free in PDCs, where two readings are possible. From the examples in (9) we can see that Slovenian ditransitives behave the same way.

(9) (a) Učitelj je [enemu učencu] dal [vsako nalogo]. teacher.nom aux [one student.dat] give.past [each task.acc]

'The teacher gave one student each task.' $* \forall>\exists>\forall$

(b) Učitelj je dal [enemu učencu] [vsako nalogo]. teacher.nom aux give.past [one student.dat] [each task.acc] 'The teacher gave one student each task.' $* \forall>\exists, \exists>\forall$

(c) Učitelj je dal [eno nalogo] [vsakemu učencu]. teacher.nom aux give.past [one task.acc] [each student.dat] 'The teacher gave one task to each student.' $\forall>\exists, \exists>\forall$

${ }^{7}$ Czech and Croatian have also been analyzed as having distinct base generated ditransitive constructions by Dvořák (2009; 2010) and Gračanin-Yuksek (2006), respectively. Both are Slavic languages with rich case systems for which Ascrambling is usually assumed to exist and have ditransitive constructions that differ only in word order. 
Like the DOC, the order DAT $\gg$ ACC in (9a) and (9b) allows only the surface reading, with the scope of the existential quantifier over the universal quantifier, while in ACC $\gg \mathrm{DAT}$ (9c), like in the PDC, both possible readings are allowed.

According to some analyses of free scope in PDCs (Pesetsky 1995), scope is free because the Theme originates in a position c-commanded by the Goal and rises above it, free scope resulting from the ability of the Theme to reconstruct to its original position. However, Bruening (2001) notes that this explanation is problematic from the point of view of interpretation as reconstruction would not be possible under his analysis, because the quantifier would not be interpretable in a position below the Goal.

The other possibility by which free scope in (9c) could be explained with a transformational approach would be to say that free scope is a consequence of the property of the existential quantifier to take scope over other quantifiers. If the Theme originated below the Goal, the existential quantifier could still take scope over the universal one in the Goal.

This can easily be shown not to be the case, since if we replace the existential quantifier with a different one, free scope is retained in the $\mathrm{ACC} \gg \mathrm{DAT}$ word order:

(10) Učitelj je dal [dve nalogi] [vsakemu učencu].

teacher.nom aux give.past [two tasks.acc] [each student.dat]

'The teacher gave two tasks to each student.' $\forall>2,2>\forall$

We offer no new explanation for the free scope in PDCs, we merely show that the Slovenian ditransitive construction represented by the word order ACC $\gg$ DAT behaves the same way in terms of scope relations as the English PDC, and contrasts the same way with DAT $\gg$ ACC as the PDC does with the DOC.

\subsection{Causative reading}

Not all ditransitive constructions allow a causative reading (as noted by Oehrle 1976 and Gračanin-Yuksek 2006). (11a) is understood as 'the presentation caused John's headache', while (11b) can only be understood the same way if to John is interpreted as somehow marked, the DOC being the unmarked ditransitive construction when expressing this type of causative relationship. 
(11) (a) The presentation gave John a headache.

(b) ${ }^{\#}$ The presentation gave a headache to John.

In the following Slovenian examples, only the DAT $\gg$ ACC word order examples in (12a-b) allow a causative reading, while ACC $\gg$ DAT (12c) does not.

(12) (a) Beethoven je svetu dal Četrto simfonijo.

Beethoven.nom aux world.dat gave Fourth Symphony.acc

'Beethoven gave the world the Fourth Symphony.'

(b) Beethoven je dal svetu Četrto simfonijo.

Beethoven.nom aux gave world.dat Fourth Symphony.acc

'Beethoven gave the world the Fourth Symphony.'

(c) ${ }^{\#}$ Beethoven je dal Četrto simfonijo svetu.

Beethoven.nom aux gave Fourth Symphony.acc world.dat

'Beethoven gave the Fourth Symphony to the world.'

(d) Beethoven je dal Četrto simfonijo dirigentu.

Beethoven.nom aux gave Fourth Symphony.acc conductor.dat

'Beethoven gave the Fourth Symphony to the conductor.'

However, the construction in (12c) is acceptable, when it describes a physical transfer or end-up-at relationship as in (12d), where the the Fourth Symphony can be understood only as the papers with the sheet music for the composition.

\subsection{Interaction with non-contrastive focus and heavy NP shift}

It was mentioned at the beginning of this section that word order in Slovenian ditransitives is relatively free, and it mostly varies due to topicalization, focus and similar processes. The purpose of this subsection is to show how certain of these processes affect the results of the tests used so far.

Živanović $(2007 ; 2008)$ notes that constituents bearing non-contrastive focus appear at the right edge of the sentence in Slovenian. Non-contrastive focus is often the answer to a question, and the best way to identify it is by using full answers to questions.

Under his analysis no movement is employed, avoiding rightward adjunction (Kayne 1994), remnant movement or the implementation of a [Focus] feature (Neeleman-van de Koot 2007), instead opting for a PF 
process that can with minor parametrization predict different language specific types of non-contrastive focus. For Slovenian, the process is essentially PF deletion not unlike the one used for the analysis of gapping, as in (13).

(13) Dumbledore je premagal Gindelwalda,

(Živanović 2008) Dumbledore.nom aux defeat.past Grindelwald.acc

Harry pa jrakensteina.

Harry.nom but Voldemort.acc

'Dumbledore defeated Grindelwald and Harry Voldemort.'

(14) (a) Kdo je za vedno premagal Mrlakensteina?

(idem.)

who.nom aux for ever defeat.past Voldemort.acc?

'Who defeated Voldemort for good?'

(b) $\left[\mathrm{BgP}_{e}\left[\mathrm{BgP}_{e^{\prime}} \mathrm{Za}\right.\right.$ vedno je $\emptyset$ premagal Mrlakensteina $]$ jarry Mrtalina

(c) Za vedno je premagal Mrlakensteina HARRY. for ever aux defeat.past Voldemort.acc Harry.nom 'It was Harry who defeated Voldemort for good.'

Following this approach, we can explain why the results of the tests described above do not change when we apply them to sentences with non-contrastive focus; the underlying structures do not change and retain both their word order and c-command relations.

This can be seen with binding (15), scope relations (16), and causative reading (17) as exemplified below:

(15) (a) Tat ${ }_{j}$ je vrnil $\left[\operatorname{svoj}_{i, j} \text { avto] [VSAKEMU OŠKODOVANCU }\right]_{i}$. thief $_{j}$ aux gave back $\left[\right.$ his $_{i, j}$ car.acc $]$ [each victim.dat $]_{i}$ 'It was to every victim that the thief returned his (or the victims) car.'

(b) Tat $_{j}$ je vrnil [vsakemu oškodovancu $]_{i}\left[\operatorname{SVOJ}_{* i, j}\right.$ AVTO $]$. thief $_{j}$ aux gave back [each victim.dat $]_{i}\left[\begin{array}{lll}\text { his }_{* i, j} & \text { car.acc }\end{array}\right.$ 'It was his car that the thief gave to every victim.'

(16) (a) Učitelj je dal [vsako nalogo] [ENEMU UČENCU]. teacher.nom aux give.past [each task.acc] [one student.dat] 'It was to one student that the teacher gave each task.' $* \forall>\exists, \exists>\forall$

(b) Učitelj je dal [vsakemu učencu] [ENO NALOGO]. teacher.nom aux give.past [each student.dat] [one task.acc] 'It was a/one task that the teacher gave to each student.' $\forall>\exists, \exists>\forall$ ' 
(17) (a) Industrializacija je Angliji prinesla obdobje gospodarske rasti. Industrialization.nom aux England.dat brought [period economic growth.acc] 'Rapid industrialization gave England a period of economic growth.'

(b) Industrializacija je prinesla obdobje gospodarske rasti ANGLIJI. Industrialization.nom aux brought [period economic growth.acc] England.dat 'It was England that industrialization gave a period of economic growth.'

Of course these sentences can also represent focused counterparts of ditransitive sentences with the same superficial word order. But the possibility of svoj binding with the Goal in (15a) and the availability of free scope (16b), neither present in non-focused sentences with the same word order, show that an analysis where the focused object's underlying position is above the other object is possible.

The fact that some speakers get readings such as those in (15b) and (16a) also strongly supports this analysis. And so does the evidence from (17), where if the dative object's underlying position was the same as the surface one, the causative reading would not be possible. So in order to get this reading, Angliji must be interpreted as originating above the accusative object.

Heavy NP shift is also an apparent rightward movement, but whereas for sentences with focus, speakers more readily provide judgments consistent with a reversed order of Theme and Goal, with heavy NP shift, speakers tend to reanalyze the underlying DAT $\gg \mathrm{ACC}$ as ACC $\gg \mathrm{DAT}$ and vice versa. This can be analyzed as constituent "weight" influencing the speakers' choice of ditransitive construction when different ones are possible with the same meaning. In such cases, the presumably "costly" heavy NP shift is avoided.

So if causative reading is only possible with the construction expressed by the DAT $\gg$ ACC word order, reanalysis would cause the sentence to be interpreted literally. Causative reading can thus only be retained when the sentence is perceived as having an underlying DAT $\gg$ ACC order, as in (17), appearing as ACC $\gg$ DAT due to heavy NP shift. The examples in (18) below confirm this.

(18) (a) Industrializacija je prinesla [nove vire zaslužka] Industrialization.nom aux bring.past [new sources profit.acc] [državam, ki so bile pripravljene zgodaj vlagati $\mathrm{v}$ novo tehnologijo]. [countries.dat that cl be.past prepared early invest in new technology] 'Industrialization brought new sources of profit to countries that were prepared to invest into new technologies early.' 
(b) \#/?? Industrializacija je prinesla [nove vire zaslužka] državam. Industrialization.nom aux bring.past [new sources profit.acc] countries.dat

Bruening (2010a) discusses quantifier scope effects in ditransitives that undergo heavy NP shift, and shows that scope relations are retained. Due to the possibility of reanalysis this cannot be tested for straightforwardly in Slovenian. The test is possible, however, with the use of the adjective drugačen 'different', which requires an element to take scope over it (Larson-Harada 2009). This means that in constructions with frozen scope it can only receive a contextual interpretation.

(19) (a) Učitelj je [(\# drugačnemu) učencu $]$ dal [vsako nalogo]. teacher.nom aux [(different) student.dat] give.past [each task.acc] 'The teacher gave a ( ${ }^{\#}$ different) student each task.'

(b) Učitelj je dal [(\# drugačnemu $)$ učencu] [vsako nalogo]. teacher.nom aux give.past [different student.dat] [each task.acc] 'The teacher gave a (\# different) student each task.'

(c) Učitelj je dal [(drugačno) nalogo] [vsakemu učencu]. teacher.nom aux give.past [(different) task.acc] [each student.dat] 'The teacher gave a (different) task to each student.'

In the examples $(19 \mathrm{a}-\mathrm{b})$ drugačen is interpreted contextually. But if the Theme is heavy as in (20) below, the interpretation expected from a construction allowing free scope is possible.

(20) Učitelj je dal [(drugačnemu) učencu] [vsako novo nalogo, teacher.nom aux gave [(different) student.dat] [each new task.acc ki si jo je izmislil med uro]. that $\mathrm{cl} \mathrm{cl}$ aux come up with.past during class]

'The teacher gave a (different) student each new task he came up with during class.'

Just as with causative meaning, reanalysis is not possible if the sentence is to have a non-contextual interpretation of the adjective drugačen. We do not make any claims about the nature of heavy NP shift, but in regards with it behaving the same way as non-contrastive focus in Slovenian, a PF process analysis is not out of the question as an alternative to $\overline{\mathrm{A}}$-scrambling or Light Predicate Raising.

We return to focus and heavy NP shift in the next section when we show how it interacts with high and low applicative meaning. 


\section{Word order and the high and low applicative readings}

\subsection{The two applicative meanings/structures in Slovenian}

In this part we show how an analysis of Slovenian ditransitive sentences in terms of Pylkkänen's high and low applicatives provides a further argument for the structures that we propose in Table 1. Here we also spell out the tree structures for Slovenian low applicatives (DOC equivalent), high applicatives and PDCs and discuss their properties.

Slovenian ditransitive sentences can receive two possible interpretations, as shown in Marvin (2009) and exemplified in (21) below. In the first interpretation of (21), where the dative object is the (intended) recipient of the direct object 'letter', the structure proposed is (21a), the so-called low applicative as in Pylkkänen (2002; 2008). This interpretation is equivalent to the English DOC. In the second interpretation of (21) (non-existent in English), where the dative object is the beneficiary of the event of sending the letter (but not a recipient of the letter), the structure proposed is Pylkkänen's high applicative, (21b). ${ }^{8}$ Some further examples that show the same ambiguity are given in $(22) .{ }^{9,10}$

${ }^{8}$ We take the semantics of the low and high applicative heads to be as proposed in Pylkkänen $(2002 ; 2008)$ and taken up by Bosse et al. (to appear) for the high applicative benefactive head.

${ }^{9}$ We follow Pylkkänen's analysis in terming low applied arguments as bearing a transfer-of-possession relation to the direct object. That includes also low applied arguments of the verbs such as bake, whose dative argument is termed 'beneficiary' in some literature, e.g., Rappaport Hovav-Levin (2005). Here, we use the term beneficiary only for what we believe are 'true' benefactive arguments, the high applied arguments.

${ }^{10}$ In our paper we use the division into high and low applicatives as in Pylkkänen (2002; 2008), though it should be noted that her analysis does not account for several properties observed in different languages and also suffers from certain problematic logical implications. To begin with the low applicative, her analysis separates the indirect object argument from the event structure of the verb, which results in logical consequences that are problematic for her proposal (implications in coordinated sentences); this is shown in Larson (2010). This problem can be avoided as for example in Bruening (2010b), where what corresponds to Pylkkänen's low applicative has essentially the same structure as her high applicative, but a different semantics. As to her high applicative, Bosse et al. (to appear) argues convincingly that Pylkkänen's definition of the high applicative is too coarse; the paper introduces four different types of non-selected arguments (external possessor construction, benefactive construction, attitude holder, affected 
(21) Bine Zoji pošilja pismo.

Bine.nom Zoja.dat send.pres letter.acc

(a) low applicative (Pylkkänen 2002):

'Bine is sending Zoja a letter.' (dative object = Recipient)

(b) high applicative (Pylkkänen 2002):

'Bine is sending a letter for Zoja (so Zoja wouldn't have to do it).' (dative object $=$ Beneficiary)

(a)

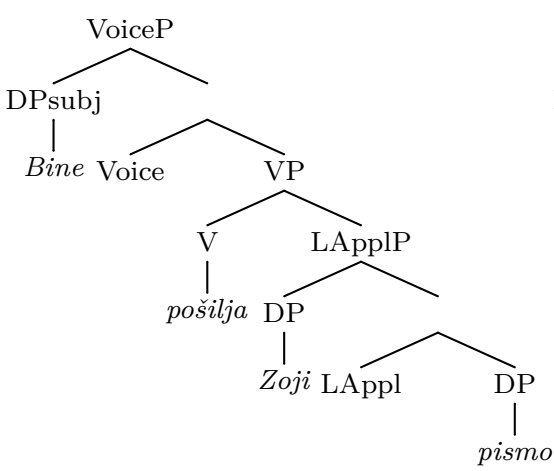

(b)

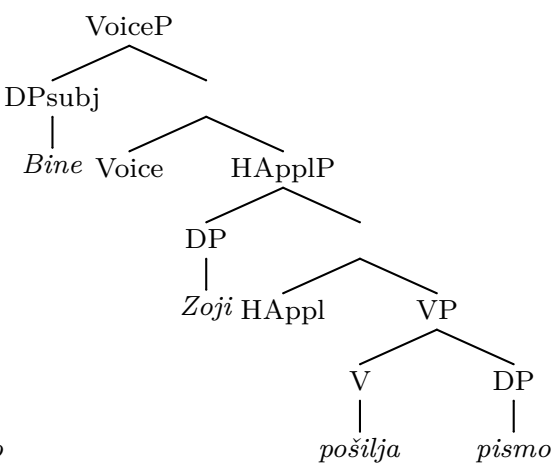

(22) (a) Binetu sem spekel torto.

Bine.dat aux.1sg baked cake.acc

'I baked Bine a cake.' or 'I baked a cake for Bine/instead of Bine.'

(b) Binetu sem vrgel žogo na streho.

Bine.dat aux1sg thrown ball.acc on roof

'I threw Bine (who was on the roof) the ball.' or 'I threw the ball onto the roof for Bine (who was not on the roof).'

(c) Telefoniral sem mu na Japonsko.

phoned aux1sg cl.3sg.m.dat to Japan.acc

'I phoned him to Japan.' or 'I phoned someone in Japan for him.'

experiencer), which all pass the diagnostics for Pylkkänen's high applicatives. Despite this criticism, Bosse et al. (to appear) keeps the exact structure and semantics as Pylkkänen's high applicative for one of their four constructions, the benefactive construction (and this is the high applicative discussed in this paper). For a critical assessment of Pylkkänen (2002; 2008) see also Boneh-Nash (2011). In our paper, we acknowledge the problems with Pylkkänen's analysis, but still keep her opposition between the low and the high applicative, because we believe that such basic distinction suffices for the purpose of this paper and the potential changes in this respect do not affect the claims with respect to the word order and the opposition between the applicative constructions and the PDC that we are trying to show exists in Slovenian.

Acta Linguistica Hungarica 59, 2012 
(d) Vrnil mu bom knjigo.

returned cl.3sg.m.dat aux.fut.1sg book.acc

'I'll give him back his book.' or 'I'll return the book for him.'

The high applicative head is sensitive to lexical class; there appears to be a selectional relationship between HAppl head and the verb in the complement in the sense that HAppl bans verbs with the only caused possession meaning component (the so-called give-type verbs) in Rappaport Hovav and Levin's (2008) classification of dative verbs, cf. Marvin (to appear). So, verbs with the root meaning 'give', 'dispossess', 'show' and 'tell' in Slovenian are only found with the low applicative reading in ditransitive sentences, $(23) .{ }^{11}$

(23) (a) Binetu sem dala sok.

Bine.dat aux given juice.acc

'I gave Bine some juice'., *'I gave some juice for Bine (so Bine wouldn't have to).'

(b) Binetu sem pokazala sobo.

Bine.dat aux shown room.acc

'I showed Bine the room.', *'I showed a room for Bine.'

(c) Binetu sem povedal zgodbo.

Bine.dat aux told story.acc

'I told Bine a story.', *'I told a story for Bine.'

Sentences with other dative verbs, a large group of which are the socalled send-type and throw-type verbs and which in Rappaport Hovav and Levin's classification show both caused motion and possession meaning, are ambiguous with respect to the two applicative readings.

\subsection{Combining the two meanings with the two word orders}

In this section we provide the tree structures of ditransitive sentences in Slovenian, taking into consideration the two possible orderings of the Theme and Goal as well as the two possible applicative meanings together with the semantic restriction discussed in section 3.1. The four combinations are summarized in Table 2.

${ }^{11}$ For a more detailed classification of verbs that appear in ditransitive sentences and are ambiguous between the high and low applicative readings and those that appear only in the low applicative reading, the reader is referred to Marvin (to appear). 
Table 2

\begin{tabular}{lllll}
\hline \multicolumn{2}{c}{ WO: Dat... } & Acc (Applicative) & & \multicolumn{2}{c}{ WO: Acc... Dat (PDC) } \\
\cline { 1 - 2 } $\begin{array}{llll}\text { give-type } \\
\text { verbs }\end{array}$ & $\begin{array}{l}\text { send- and throw-type } \\
\text { verbs }\end{array}$ & & $\begin{array}{l}\text { give-type } \\
\text { verbs }\end{array}$ & $\begin{array}{l}\text { send- and throw-type } \\
\text { verbs }\end{array}$ \\
\hline low applicative & $\begin{array}{l}\text { low applicative } \\
\text { high applicative }\end{array}$ & & PDC & PDC \\
\cline { 1 - 2 } & & & \\
\hline
\end{tabular}

We begin by describing the possible structures that send-type and throwtype verbs can appear in, exemplified in (24) with both possible distributions of the accusative and dative argument.

(24) (a) Bine pošilja Zoji pismo. (applicative/(low, high))

Bine.nom send.pres Zoja.dat letter.acc

'Bine is sending sending Zoja a letter.' or 'Bine is sending a letter for Zoja.'

(b) Bine pošilja pismo Zoji. (PDC)

Bine.nom send.pres letter.acc Zoja.dat

'Bine is sending a letter to Zoja'

In the word order DAT $\gg$ ACC ditransitive sentences with these verbs will yield two possible meanings with the corresponding structures, the low and the high applicative one, spelled out in trees like those in (21a-b) above. In both of these structures the dative DP asymmetrically c-commands the Theme DP; given Bruening's (2001) analysis we thus expect a frozen scope in both low and high reading, which is exactly the case in Slovenian, as shown in $\mathbf{2 . 2}$.

If the word order is ACC $\gg \mathrm{DAT}$, the structure is not applicative, but a PDC, where the dative DP is a complement of a (phonologically null) prepositional head $\mathrm{P},{ }^{12}$ as in (25).

12 One of the reviewers points out that positing a silent $\mathrm{P}$ does not explain why in Slovenian the Goal receives morphological dative in both applicative and PDC constructions. But note that such approaches to languages that seem to differentiate ditransitive constructions only in terms of word order have been explored before. For example in Dvořák (2009) different syntactic heads can assign the same morphological case (dative). And layered approaches to case, such as the one presented in Caha (2009), allow for the possibility that morphological dative can itself be a superset of different syntactic/morphological heads that appear as one case marker in certain languages and separate markers in others.

Acta Linguistica Hungarica 59, 2012 
(25) The structure for ACC $\gg$ DAT

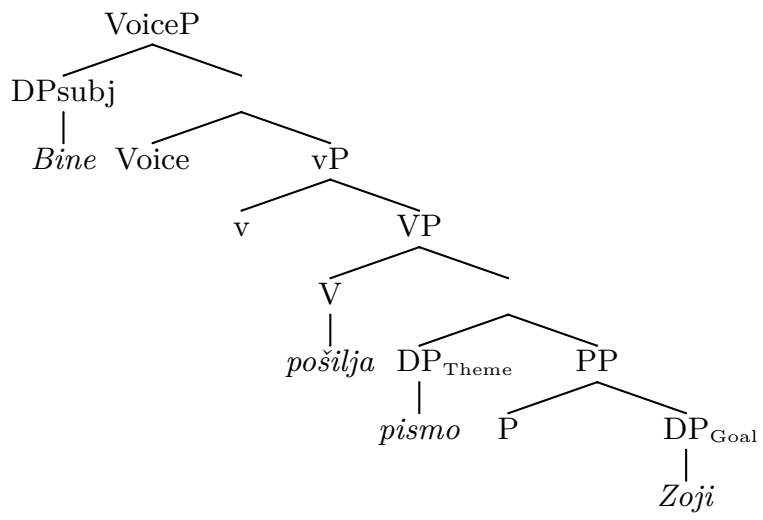

Following Bruening's (2001) analysis, a free scope in such cases is expected given the fact that in this structure the Theme DP and the Goal $\mathrm{PP}$ are two constituents in a symmetric relation. The semantic content of $\mathrm{P}$ can roughly be described as one establishing a goal/recipient relationship between the Theme and the dative DP, which is in line with Gračanin-Yuksek's proposal. ${ }^{13}$

Given the semantics of $\mathrm{P}$, which is very similar to the semantics of the low applicative, it is predicted that the word order ACC $\gg$ DAT can only yield an interpretation that comes close in meaning to the interpretation of a low applicative in (21a), but not a high-applicative-like interpretation. The data confirms this prediction, since even sentences with send-type and throw-type verbs never appear with the beneficiary reading found with these verbs in high applicatives in the DAT $\gg$ ACC word order. This fact is important because it argues for the existence of the PDC structure with a prepositional head that provides the meaning of a recipient goal for its complement DP and as such excludes any other meaning, e.g., a high applicative-like benefactive meaning. If we do not take into consideration the order of dative and accusative arguments and consequently posit this particular structure for the ACC $\gg$ DAT word order, then we cannot really explain why in this order the high applicative reading of the ditransitive sentence found in the DAT $\gg$ ACC order disappears when the order of arguments is reversed. ${ }^{14}$

${ }^{13}$ Gračanin-Yuksek (2006) proposes an HP instead of a PP, where the (null) head $\mathrm{H}$ establishes an end-up-at relationship.

14 The PDC (ACC $\gg$ DAT) and the low applicative (DAT $\gg$ ACC) are indeed very close in meaning, but their structural properties are crucially different in terms 
The structures that occur in ditransitives with give-type verbs are exactly the same as those of send-type and throw-type verbs; however, give-type verbs lack the high applicative reading/structure altogether. The two possible readings are given in the example below, with the structures of the low applicative in (21a-b) and the PDC in (25), respectively.

(26) (a) Bine je ponudil Zoji torto. (applicative/low)

Bine.nom aux offered Zoja..dat cake.acc

'Bine offered some cake to Zoja.'

(b) Bine je ponudil torto Zoji. (PDC)

Bine.nom aux offered cake.acc Zoja.dat

'Bine offered some cake to Zoja.'

\subsection{Interaction between HAppl, LAppl, and PP}

Since Slovenian seems to have three different syntactic means of expressing IO/DO combinations, it is an ideal testing ground for examining in what way all these different constructions interact with each other. ${ }^{15}$ The initial hypothesis is that all these constructions can appear in a sentence at the same time and this seems to be the case, as seen in (27), where the HAppl $(t i)$ and LAppl (Evi) appear together.

(27) Napisal ti bom Evi pesem.

write.past cl.2sg.dat aux.1sg Eva.dat poem.acc

'I'll write a poem to Eva for you.'

If Slovenian really has a HAppl head, this would mean it should be able to occur together with an unergative verb. As noted in Marvin (to appear), this is possible:

(28) Dojenček ji spi celo noč. baby.nom cl sleep.pres all night

'The baby sleeps through the night.'

of scope and binding of possessives. The fact that they are close in meaning is not problematic, since in many cases dative DPs can be 'paraphrased' by a PP (e.g., by a for- or a to-phrase). In a sense the two could also be analyzed as low applicatives, but with a reversed directionality of arguments, however, we leave this possibility to be investigated in future research.

${ }^{15}$ We thank one of the anonymous reviewers for stressing the importance of this issue to us, making us include this as a separate subsection. 
Also the HAppl and the PP can appear in the same sentence:

(29) Napisal je prijatelju $_{i}$ pesem njegovi $i_{i}$ punci. write.past aux.3sg friend.dat poem.acc [his ${ }_{i}$ girlfriend.dat]

'He wrote a song to his friend's girlfriend for his friend.'

This leaves us with the LAppl and PP, which is an impossible combination, as we can see when we use a verb that does not allow a high applicative reading:

(30)*Dal je prijatelju $_{i}$ darilo njegovi punci.

give.past aux.3sg friend.dat gift.acc [his ${ }_{i}$ girlfriend.dat]

'*He gave a friend $i$ a gift to his ${ }_{i}$ girlfriend.'

While this could be seen as evidence that LAppl and PP are one and the same, note that this sort of construction with this meaning is also impossible in English, for which two distinctive constructions are generally assumed.

\subsection{Applicatives, non-contrastive focus and heavy NP shift}

We now return to non-contrastive focus and heavy NP shift (cf. section 2.4). The prediction is that under non-contrastive focus and heavy NP shift the low and high applicative readings will be retained even though the order of the Theme and Goal is reversed.

Non-contrastive focus:

(31) (a) Napisal sem esej sošolcu.

write.past aux.1sg essay.acc classmate.dat

'It was for a classmate that I wrote the essay.'

(b) Dal sem svinčnik sošolCU.

give.past aux.1sg pencil.acc classmate.dat

'It was to a classmate that I gave the pencil.'

Heavy NP shift:

(32) (a) Napisal sem esej [sošolcu, ki ga nikoli ne napiše sam]. write.past aux.1sg essay.acc [classmate.dat who cl never not write alone] 'I wrote an essay for a classmate who never writes it himself.' 
(b) Napisal je pesem [sošolki, ki mu je bila že write.past aux.3sg poem.acc [classmate.dat who cl aux be.past already dolgo všeč].

long like]

'He wrote a poem to a classmate whom he liked for a long time.'

The examples above show our prediction to be correct and in line with the results for the rest of the cases of ditransitives with focused and heavy NP shifted constituents.

\subsection{Idiom formation}

We indicated in section 2 that, based on the behavior of idioms, it cannot be proved (if not disproved) that Slovenian ditransitives are related to each other by A-scrambling or some other operation deriving one construction from another.

But assuming the theory of idiom formation presented in Bruening (2010a) we can make a stronger claim about the structures of Slovenian ditransitives, one that is in line with the structures proposed in this section.

Bruening's theory relies on the following principle (items (24), (25) and (26) from Bruening 2010a are repeated here as (33), (34) and (35), respectively):

(33) The Principle of Idiomatic Interpretation

(Bruening 2010a)

$\mathrm{X}$ and $\mathrm{Y}$ may be interpreted idiomatically only if $\mathrm{X}$ selects $\mathrm{Y}$.

\section{(34) Constraint on Idiomatic Interpretation}

If $\mathrm{X}$ selects a lexical category $\mathrm{Y}$, and $\mathrm{X}$ and $\mathrm{Y}$ are interpreted idiomatically, all of the selected arguments of $\mathrm{Y}$ must be interpreted as part of the idiom that includes $\mathrm{X}$ and $\mathrm{Y}$.

(35) Lexical categories are V, N, A, Adv.

Assuming an asymmetric analysis of English ditransitives, this predicts the following three classes of ditransitive idioms as well as the unaccountability of the fourth class (item (34) from Bruening 2010a repeated here as $(36))$ : 
(a) Class 1: Verb NP $\underline{\text { NP }}$ (give $\mathrm{X}$ the creeps)

(b) Class 2: Verb NP to NP (give rise to $\mathrm{X}$ )

(c) Class 3: $\underline{\text { Verb }} \mathrm{NP}$ to NP (send $\mathrm{X}$ to the showers)

(d) Class 4: $\underline{\mathrm{N}} \mathrm{NP} \mathrm{NP}$ (nonexistent)

The data for Slovenian matches the English data, see (37)-(39) below:

(37) Appl selects V and V selects $\mathrm{NP}_{\text {Theme }}$ : dati X košarico/give X a basket

(a) Zoja je dala Binetu košarico.

Zoja.nom aux give.past Bine.dat basket.acc

'Zoja dumped Bine.'

(b) ${ }^{\#}$ Zoja je dala košarico Binetu

Zoja.nom aux give.past basket.acc Bine.dat

(38) Voice selects $\mathrm{V}$ and $\mathrm{V}$ selects $\mathrm{NP}_{\text {Theme }}$ and $\mathrm{P}$ : prodati dušo $X /$ sell soul to $X$

(a) Bine je prodal dušo rokenrolu.

Bine.nom aux sell.past soul.acc rock n'roll.dat

'Bine sold his soul to rock n' roll.'

(b) ${ }^{\#}$ Bine je prodal rokenrolu dušo.

Bine.nom aux sell.past rock n'roll.dat soul.acc

(39) V selects $\mathrm{P}$ and $\mathrm{P}$ selects $\mathrm{NP}_{\mathrm{Goal}}$ : prepustiti $X$ usodi/leave $X$ to fate

(a) Kapitan je prepustil potnike usodi.

Captain.nom aux leave.past passengers.acc fate.dat

'The captain left the passengers to their fate.'

(b) ${ }^{\#}$ Kapitan je prepustil usodi potnike.

Captain.nom aux leave.past usodi.dat passengers.acc

The fourth class is to our knowledge also absent in Slovenian. And so is interestingly the possibility of idioms that alternate between Class 1 and Class 2, as a different word order is always marked with Slovenian idiomatic ditransitives. But this is not a problem, since this only excludes idioms formed by $\mathrm{V}$ selecting only the NP. This might be attributed in some way to the fact that both P and Appl are silent in Slovenian.

In any case, the criticism of symmetrical analyses of English ditransitives in Bruening (2010a) applies here to derivational analyses of Slovenian ditransitives, since the presence and absence of only certain 
types of idioms, shows that idioms have to be formed with two different syntactic heads-Appl and P.

\section{Some remaining issues}

\subsection{Comparison with Dvořák (2010)}

In this part we address a proposal by Dvořák (2010) since it touches on the issue of different word orders of dative and accusative arguments yielding different configurations and as such indirectly supports the structures we propose. Dvořák (2010) divides Czech ditransitives according to the nature of the verb into verbs that appear in the DAT $\gg \mathrm{ACC}$ order and those that appear in the ACC $\gg$ DAT order. The list of verbs she provides is given in (40) and (41).

(40) $\mathrm{DAT} \gg \mathrm{ACC}$

Dat-Acc verbs with recipient meaning:

dát, darovat 'give as a gift', věnovat 'inscribe/dedicate', poslat 'send', připsat 'assign', odpustit 'forgive', vrátit 'return', poskvtnout 'provide', přidělit 'allot', zadat 'place an order', zakázat 'forbid', etc.

Dat-Acc verbs with benefactive/malefactive meaning:

dělat (naschvál) 'do (on purpose)', vyrábět 'make', věrit 'believe', vařit 'cook', vybojovat 'fight out', ukrást 'steal', ztratit 'loose', zranit 'wound', chválit 'praise', poprút 'deny', pripomenout 'remind', etc.

(41) $\mathrm{ACC} \gg \mathrm{DAT}$

Acc-Dat verbs:

vystavit 'expose', zasvětit 'devote', svěrìt 'entrust', zanechat 'leave', podřidit 'subordinate, accommodate', podrobit 'put sb. through sth', príizpưsobit 'adjust', pripodobnit 'liken', předurčit 'predestine', etc.

The two groups appear with two different syntactic configurations. Ditransitive sentences with DAT $\gg$ ACC verbs in (40) have a structure equivalent to our low applicative structure, where their dative case is assigned by $\mathrm{v}_{\mathrm{Appl}}$. Ditransitive sententences with ACC $\gg$ DAT verbs in (41), on the other hand, have a structure equivalent to our PDC, where the dative case is assigned by a non-overt P. ${ }^{16}$

${ }^{16}$ Dvořák (2010) does not posit a high applicative structure for any of the verbs, but that does not mean that such structure does not exist in Czech. 
Our structures based on word order are practically identical to the structures proposed by Dvořak based on word order, but the dependence of the word order on the lexical class of verb needs to be more thoroughly investigated in Slovenian, since not all verbs in Slovenian display such a sharp contrast as to the word order in which they can appear. For example, the verb dati 'give' can appear with both word orders, (42), unlike the verb dát, darovat 'give' in Czech, where the DAT $\gg$ ACC order is the only one possible. The verb izpostaviti 'expose', on the other hand, is like the Czech verbs in (43), only appearing in the ACC $\gg$ DAT, $(43)^{17}$.

(42) (a) Učitelj je otrokom dal knjige. teacher.nom aux children.dat given books.acc

'The teacher gave the children some books.'

(b) Učitelj je dal knjige otrokom.

teacher.nom aux given books.acc children.dat

'The teacher gave some books to the children.'

(43) (a) Učitelj je otroke izpostavil nevarnosti. teacher.nom aux children.acc exposed danger.dat

'The teacher exposed the children to danger.'

(b) ${ }^{\#}$ Učitelj je nevarnosti izpostavil otroke.

teacher.nom aux danger.dat exposed children.acc

\subsection{Pure locatives in PDCs}

One of the well-known tests that distinguishes between PDCs and DOCs is the compatibility of the PDCs, (44b), and incompatibility of the DOCs, (44a), with pure locative Goals.

(44) (a) *I sent Toronto the letter.

(DOC)

(b) I sent the letter to Toronto.

$(\mathrm{PDC})$

It would thus be reasonable to expect that in Slovenian the PDC is compatible with pure locatives, while applicative structures are not. However, none of the structures is compatible with pure locatives, as seen in (45).

${ }^{17}$ Except in cases consistent with the discussion on focus and heavy NP shift in sections 2.4 and 3.4. 
(45) (a) *Poslal sem Torontu pismo. (applicative) sent aux Toronto.dat letter.acc intended: 'I sent Toronto the letter.'

(b) *Poslal sem pismo Torontu. (PDC) sent aux letter.acc Toronto.dat intended: 'I sent the letter to Toronto.'

We propose that such behavior is ascribed to the requirement that, in Slovenian, locative Goals have to be expressed with an overt preposition, as can be seen in (46) and (47).

(46) Poslal sem pismo v Toronto.

sent aux letter.acc to Toronto.acc

'I sent the letter to Toronto'

(47) Šli smo *Torontu / k Torontu / v Toronto.

gone aux ${ }^{*}$ Toronto.dat / near Toronto.dat / to Toronto.acc

'We went near/to Toronto'

All cases of dative arguments in PDCs up to this section were cases of recipient Goals and these do not have a requirement on an overt preposition in the $\mathrm{P}^{18}$

\section{Conclusion}

Slovenian is a language that allows low as well as high applicatives with ditransitive verbs, albeit with certain restrictions. High applicatives are disallowed in a lexically conditioned environment, i.e., with give-type verbs. In this paper we show that the availability of high applicatives is restricted also by the word order of the objects, the high applicative reading only appearing in the DAT $\gg$ ACC but not in the ACC $\gg$ DAT order. This restriction on the high applicative reading provides another argument for the claim that the two word orders are surface realizations of two essentially different "deep structures", as proposed in Gračanin-Yuksek (2006) for Croatian. Following Gračanin-Yuksek, we propose that the $\mathrm{DAT} \gg \mathrm{ACC}$ order is applicative-like, while the ACC $\gg$ DAT is PDC-like. Compared to their English counterparts, the two Slovenian constructions

18 See Haspelmath (1999) for an alternative possibility of explaining this issue. 
give the same results when examined with standard tests for ditransitives, the only difference being that, in addition to the low applicative reading, Slovenian DAT $\gg$ ACC sentences can also show a high applicative reading that is lacking in English. The DAT $\gg$ ACC order in Slovenian can thus result in two possible structures: a DOC (or a low applicative as in Pylkkänen 2002; 2008) and a high applicative structure as in Pylkkänen $(2002 ; 2008)$. The ACC $\gg$ DAT order, however, is essentially a PDC (an analogue of the English to-object structure), where the dative DP is a complement of a phonologically null prepositional head P, which establishes the semantic relationship of a recipient goal between the Theme and the dative DP. Ditransitive sentences with the ACC $\gg$ DAT order are thus incapable of "acquiring" a high applicative reading, usually found with the reversed order of arguments. This paper adds new restrictions to different applicative readings in Slovenian, makes new claims about the nature of Slovenian ditransitive constructions, shows the link between the high and low applicative and the different ditransitive constructions, and opens up new questions about the nature of them for future research.

\section{References}

Aoun, Joseph - Audrey Yun-Hui Li 1989. Scope and constituency. In: Linguistic Inquiry $20: 141-72$.

Barss, Andrew-Howard Lasnik 1986. A note on anaphora and double objects. In: Linguistic Inquiry $17: 347-54$.

Boneh, Nora - Léa Nash 2011. High and higher applicatives: The case of French non-core datives. In: Mary Byram Washburn - Katherine McKinney-Bock-Erika Varis Ann Sawyer-Barbara Tomaszewicz (eds): Proceedings of the 28th West Coast Conference on Formal Linguistics, 60-8. Cascadilla Press, Sommerville MA.

Bosse, Solveig-Benjamin Bruening-Masahiro Yamada to appear. Affected experiencers. In: Natural Language and Linguistic Theory.

Bruening, Benjamin 2001. QR obeys superiority: Frozen scope and ACD. In: Linguistic Inquiry $17: 233-73$.

Bruening, Benjamin 2010a. Ditransitive asymmetries and a theory of idiom formation. In: Linguistic Inquiry $41: 519-62$.

Bruening, Benjamin 2010b. Double object constructions disguised as prepositional datives. In: Linguistic Inquiry $41: 287-305$.

Caha, Pavel 2009. The nanosyntax of case. Doctoral dissertation, University of Troms $\emptyset$.

Dvořák, Věra 2009. Ditransitive verbs in Czech and their nominalizations. Qualifying paper. Department of Linguistics Graduate School, New Brunswick Rutgers, The State University of New Jersey. 
Dvořák, Věra 2010. On the syntax of ditransitive verbs in czech. In: Wayles BrowneAdam Cooper-Alison Fisher-Esra Kesici-Nikola Predolac-Draga Zec (eds): Formal approaches to Slavic linguistics 19: The Second Cornell Meeting 2009, 161-77. Michigan Slavic Publications, Ann Arbor.

Gračanin-Yuksek, Martina 2006. Double object construction in Croatian: Arguments against $\mathrm{Appl}^{0}$. In: Richard Compton-Magdalena Goledzinowska-Ulyana Savchenko (eds): Formal approaches to Slavic linguistics 13: The Toronto Meeting 2005, 94-112. Michigan Slavic Publications, Ann Arbor.

Haspelmath, Martin 1999. External possession in a European areal perspective. In: Doris L. Payne-Immanuel Barshy (eds): External possesion, 109-35. John Benjamins, Amsterdam \& Philadelphia.

Jackendoff, Ray 1990. On Larson's treatment of the double object construction. In: Linguistic Inquiry 21(3) : 427-56.

Kayne, Richard S. 1994. The antisymmetry of syntax. MIT Press, Cambridge MA.

Larson, Richard 1988. On the double object construction. In: Linguistic Inquiry 19: 335-91.

Larson, Richard K. 2010. On Pylkkänen's semantics for low applicatives. In: Linguistic Inquiry $41: 701-4$.

Larson, Richard K.-Naomi Harada 2009. Datives in Japanese. In: Ryosuke Shibagaki-Reiko Vermeulen (eds): Proceedings of the 5th Workshop on Altaic Formal Linguistics (WAFL5) (MIT Working Papers in Linguistics 54), 3-17. MIT, Cambridge, MA.

Marvin, Tatjana 2009. Applicative constructions in Slovenian. In: Vrinda Chidambaram-Steven Franks-Brian D. Joseph (eds): A linguist's linguist: Studies in South Slavic linguistics in honor of E. Wayles Browne, 297-315. Slavica, Bloomingdale.

Marvin, Tatjana to appear. A note on applicatives. In: Maria Cristina Cuervo-Yves Roberge (eds): The end of argument structure? Syntax and Semantics 38, 185208. Emerald, Bradford.

McGinnis, Martha 1999. A-scrambling exists! In: Michelle Minnick-Na-Rae Han (eds): Proceedings of the 23rd Annual Penn Linguistics Colloquium, 283-97. Penn Working Papers in Linguistics, University of Pennsylvania.

Miyagawa, Shigeru 1997. Against optional scrambling. In: Linguistic Inquiry 28:1-25.

Neeleman, Ad-Hans van de Koot 2007. The nature of discourse templates. Ms. (http://www.phon.ucl.ac.uk/home/ad/publications).

Oehrle, Richard Thomas 1976. The grammatical status of the English dative alternation. Doctoral dissertation, Massachusetts Institute of Technology.

Pesetsky, David 1995. Zero syntax: Experiencers and cascades. MIT Press, Cambridge MA.

Pylkkänen, Liina 2002. Introducing arguments. Doctoral dissertation, Massachusetts Institute of Technology.

Pylkkänen, Liina 2008. Introducing arguments. MIT Press, Cambridge MA.

Rappaport Hovav, Malka-Beth Levin 2005. Argument realization. Cambridge University Press, Cambridge UK.

Acta Linguistica Hungarica 59, 2012 
Rappaport Hovav, Malka-Beth Levin 2008. The English dative alternation: The case for verb sensitivity. In: Journal of Linguistics 44:129-67.

Stegovec, Adrian to appear. Dokazi za dve različni dvopredmetni zgradbi v slovenščini [Evidence for two separate ditransitive constructions in Slovenian]. In: Škrabčevi dnevi 7.

Živanović, Sašo 2007. Kvantifikacijski vidiki logične oblike v minimlistični teoriji jezika [Quantificational aspects of LF]. Doctoral dissertation, Univerza v Ljubljani.

Živanović, Sašo 2008. On sentence-final realisation of focus. Paper presented at the Sarajevo Linguistic Gathering 3. 